\title{
EVALUASI PENDIDIKAN ISLAM
}

\author{
Ismail Marzuki* Lukmanul Hakim** \\ ismailmarzuki@umt.ac.id,lukman@umt.ac.id \\ *Dosen Fakultas Agama Islam, Universitas Muhammadiyah Tangerang \\ **Dosen Fakultas Agama Islam, Universitas Muhammadiyah Tangerang
}

\begin{abstract}
Education is a conscious effort and responsibility to nurture, guide and direct the growth and development of the lives of students, so that it has the meaning and purpose of an essential life. While the educational process aims to cause desired changes in each student. The desired changes in students include three fields, namely: (1) personal goals and those related to individuals who are learning for the desired changes, both changes in behavior, activities and achievement, and desired growth for participants students; (2) social goals related to people's lives as social beings along with the general dynamics of society; (3) professional goals related to education and teaching as a science, art and profession. The educational process in question is inseparable from several supporting components. One component that is urgent in seeing the success of education is evaluation.
\end{abstract}

Keywords: Education, Learning, Evaluation.

\section{A. PENDAHULUAN}

Manusia adalah makhluk yang tumbuh dan berkembang. Ia ingin mencapai suatu kehidupan yang optimal. Selama manusia berusaha untuk meningkatkan kehidupannya, baik dalam meningkatkan dan mengembangkan pengetahuan, kepribadian, maupun keterampilannya, secara sadar atau tidak sadar, maka selama itulah pendidikan terus berlangsung.

Pendidikan Islam merupakan pendidikan yang didasarkan pada nilai-nilai ajaran Islam sebagaimana tercantum dalam al-Qur'an dan al-Hadits serta dalam pemikiran para ulama dan dalam praktik sejarah umat Islam. ${ }^{1}$ Dalam prosesnya, pendidikan Islam menjadikan tujuan sebagai sasaran ideal yang hendak dicapai dalam program dan diproses dalam produk kependidikan Islam atau output

\footnotetext{
1 Abudin Nata, Manajemen Pendidikan, Mengatasi Kelemahan Pendidikan Islam di Indonesia, (Jakarta: Prenada Media Group, 2008), cet ke.3, 173.10
}

kependidikan

Islam.

Adagium ushuliyah menyatakan bahwa: "al-umûr bi maqâshidika", bahwa setiap tindakan dan aktivitas harus berorientasi pada tujuan atau rencana yang telah ditetapkan. $^{3}$

Untuk mengetahui ketercapaian suatu tujuan kegiatan yaitu evaluasi. Dengan evaluasi, maka suatu kegiatan dapat diketahui atau ditentukan taraf kemajuannya. Berhasil atau tidaknya pendidikan Islam dalam mencapai tujuannya dapat dilihat setelah dilakukan evaluasi terhadap output yang dihasilkannya. Abdul Mujib dkk mengungkapkan bahwa untuk mengetahui pencapaian tujuan pembelajaran atau kompetensi yang diharapkan oleh peserta

\footnotetext{
2 M. Arifin, Ilmu Pendidikan Islam, Tinjauan Teoritis dan Praktis Berdasarkan Pendekatan Interdisipliner, (Jakarta: Bumi Aksara, 2009), 162.

3 Abdul Mujib dan Jusuf Mudzakkir, Ilmu Pendidikan Islam, (Jakarta: Kencana Prenada Media Group, 2008), cet. ke 2, 72.
}

Tadarus Tarbawy. Vol. 1 No. 1 Jan-Jun 2019. 
didik diperoleh melalui evaluasi. ${ }^{4}$ Dengan kata lain penilaian atau evaluasi digunakan sebagai alat untuk menentukan suatu tujuan pendidikan dicapai atau tidak. Atau untuk melihat sejauhmana hasil belajar siswa sudah mencapai tujuannya.

Dalam pendidikan Islam evaluasi merupakan salah satu komponen dari sistem pendidikan Islam yang harus dilakukan secara sistematis dan terencana sebagai alat untuk mengukur keberhasilan atau target yang akan dicapai dalam proses pendidikan Islam dan proses pembelajaran.

\section{B. PEMBAHASAN}

\section{Pengertian Evaluasi Pendidikan}

Evaluasi berasal dari kata to evaluate yang berarti menilai. Nilai dalam bahasa arab disebut al qimat. istilah nilai ini mulanya dipopulerkan oleh para filsuf. Dalam hal ini, plato merupakan filsuf yang pertama kali mengemukakannya. Pembahasan "'nilai', secara khusus di perdalam dalam diskursus filsafat, terutama pada aspek oksiologinya. Begitu penting kedudukan nilai dalam filsafat sehingga para filsuf meletakan nilai sebagai muara bagi epistemologi dan antologi filsafat. Kata nilai menurut filsuf adalah idea of worth.

Meskipun kini memiliki makna yang lebih luas, namun pada awalnya pengertian evaluasi pendidikan selalu dikaitkan dengan prestasi belajar siswa. Definisi yang pertama dikembangkan oleh Ralph Tyler (1950), mengatakan bahwa evaluasi merupakan sebuah proses pengumpulan data untuk menentukan sejauh mana, dalam hal apa, bagian mana tujuan pendidikan sudah tercapai. Jika belum, bagaimana yang belum dan apa sebabnya. Definisi yang lebih luas dikemukakan oleh dua orang ahli lain, yakni Cronbach dan

4 Ramayulis. 2008. Ilmu Pendidikan Islam, Jakarta:Kalam Mulia, cet. ke 10, hal: 220.

Ibid. h. 221
Stufflebeam, mendefinisikan bahwa proses evaluasi bukan sekedar mengukur sejauh mana tujuan tercapai, tetapi digunakan untuk membuat keputusan. ${ }^{6}$

Evaluasi pendidikan dalam Islam dapat diberi batasan sebagai suatu kegiatan untuk menentukan kemajuan suatu pekerjaan dalam proses pendidikan Islam. Dalam ruang lingkup terbatas, evaluasi dilakukan dalam rangka mengetahui tingkat keberhasilan pendidik dalam menyampaikan materi pendidikan Islam pada peserta didik, sedangkan dalam ruang lingkup luas, evaluasi dilakukan untuk mengetahui tingkat keberhasilan dan tingkat kelemahan suatu proses pendidikan Islam (dengan seluruh komponen yang terlibat didalamnya) dalam mencapai tujuan pendidikan yang dicita-citakan.

Penilaian dalam pendidikan dimaksudkan untuk menetapkan berbagai keputusan kependidikan, baik yang menyangkut perencanaan pengelolaan, proses dan tindak lanjut pendidikan, baik yang menyangkut perorangan, kelompok maupun kelembagaan.

Disamping evaluasi terdapat pula istilah measurement, measurement berasal dari kata to measure yang berarti mengukur, measurement berarti perbandingan data kualitif dengan data kuantitatif yang lainnya yang sesuai dalam kerangka mendapatkan nilai (angka). Pengukuran dalam pendidikan adalah usaha untuk memahami kondisikondisi objektif tentang sesuatu yang akan dinilai. Dalam pendidikan islam, evaluasi akan objektif apabila didasarkan dengan tolak ukur Al-Qur'an atau Hadits.

Suharsimi Arikunto membedakan tiga istilah tersebut, yaitu pengukuran, penilaian, dan evaluasi. Pengukuran adalah membandingkan

6 Arikunto, Suharsimi. 2012. Dasar-dasar Evaluasi Pendidikan, Jakarta: Bumi Aksara, cet. ke 10, hal: 3. 
sesuatu dengan

ukuran. Pengukuran ini bersifat kuantitatif. penilaian adalah mengambilan suatu keputusan terhadap sesuatu dengan ukuran baik dan buruk secara kualitatif. Sementara evaluasi adalah mencakup pengukuran dan penilaian secara kuantitatif. ${ }^{7}$

Dalam al-qur'an atau hadits, banyak sekali ditemui tolak ukur evaluasi dalam pendidikan islam misalnya tolak ukur sholat yang baik dan sempurna adalah mencegah orang dari perbuatan keji dan munkar, tolak ukur watak seseorang yang beriman adalah bila melaksanakan sholat secara khusyuk, membayar zakat (Qs. alNisa:162) menjaga kemaluan terhadap wanita yang bukan istri. Tolak ukur perilaku seseorang yg beriman adalah mencintai saudaranya seperti mencintai dirinya sendiri (Qs. al-Baqorah:148). Tolak ukur seseorang yang munafik disebutkan oleh Nabi dalam tiga indikasi, yaitu dusta dalam berbicara, ingkar dalam berjanji, dan khianat apabila diberi kepercayaan (amanah). ${ }^{8}$

Term evaluasi dalam wacana keislaman tidak dapat ditemukan padanan yang pasti, tetapi terdapat term-term tertentu yang mengarah pada makna evaluasi. Berikut ini penjelasan term-term tersebut: (1) AlHisab, memiliki makna mengira, menafsirkan dan menghitung; (2) Al-bala, makna cobaan, ujian; (3) Al-hukm, memiliki makna putusan atau vonis; (4) Al-qodha, memiliki makna putusan; (5) Al-nazhr, memiliki arti melihat.

Dalam pendidikan islam, tujuan evaluasi lebih ditekankan pada penguasaan sikap (afektif dan psikomotor) ketimbangan aspek kognitif). Penekanan ini bertujuan untuk mengetahui kemampuan peserta didik yang secara garis besar meliputi 4 hal yaitu sebagai berikut:

$7 \quad$ Ibid

8 Ramayulis. 2008. Ilmu Pendidikan Islam, Jakarta:Kalam Mulia, cet. ke 10, hal: 235-236.
1. Sikap dan pengalaman terhadap hubungan pribadinya dengan tuhannya.

2. Sikap dan pengalaman terhadap arti hubungan dirinya dengan masyarakat.

3. Sikap dan pengalaman terhadap arti hubungan kehidupannya dengan alam sekitarnya.

4. Sikap dan pandangan terhadap dirinya sendiri selaku hamba allah, anggota masyarakat, serta khalifah allah.

\section{Objek Evaluasi Pendidikan}

Objek evaluasi pendidikan Islam dalam arti yang umum adalah peserta didik. Sementara dalam arti khusus adalah aspek-aspek tertentu yang terdapat pada peserta didik. Peserta didik disini sebenarnya bukan hanya sebagai objek evaluasi semata, melainkan pula sebagai subjek evaluasi. Evaluasi pendidikan Islam dapat di lakukan dengan dua cara yaitu: (1) evaluasi diri sendiri; (2) evaluasi terhadap orang lain (peserta didik). Evaluasi terhadap diri sendiri adalah dengan mengadakan intropeksi atau perhitungan terhadap diri sendiri. Evaluasi ini tentunya berdasarkan kesadaran internal yang bertujuan untuk meningkatkan kreativitas dan produktivitas (amal shaleh) pribadi. Apabila dalam proses evaluasi tersebut ditemukan beberapa keberhasilan, keberhasilan itu hendaknya dipertahankan atau ditingkatkan. Akan tetapi, apabila ditemukan beberapa kelemahan dan kelemahan, hendaknya hal segera diperbaiki dengan cara meningkatkan ilmu, iman, dan amal ( $\mathrm{Al}$ -Banna, 1990: 12).

\section{Tujuan dan Fungsi Evaluasi Pendidikan Islam}

Dalam setiap kegiatan evaluasi, langkah pertama yang harus diperhatikan adalah tujuan evaluasi. 
Menurut Gilbert Sax (1980) mengemukakan tujuan evaluasi dan pengukuran adalah untuk "Selection, placement, diagnosis and remediation, feedback: norm-referenced and criterion-refer-enced interpretation, motivation and guidance of learning, program and curriculum improvement: formative and summative evaluations, and theory development." 9

Kemudian dikemukakan oleh Tylor bahwa tujuan evaluasi adalah untuk mengembangkan suatu kebijakan yang bertanggungjawab mengenai pendidikan. ${ }^{10}$ Sedangkan menurut Popham menyatakan bahwa tujuan evaluasi ialah untuk membuat keputusan yang lebih baik. ${ }^{11}$

Evaluasi banyak digunakan dalam berbagai bidang dan kegiatan, antara lain dalam kegiatan bimbingan dan penyuluhan, supervise, seleksi dan pembelajaran. Setiap bidang atau kegiatan tersebut memiliki tujuan yang berbeda. Dalam kegiatan bimbingan, tujuan evaluasi adalah untuk memperoleh informasi secara menyeluruh mengenai karakteristik peserta didik, sehingga dapat diberikan bimbingan dengan sebaik-baiknya. Begitu juga dalam kegiatan supervise, tujuan evaluasi adalah untuk menentukan keadaan suatu situasi pendidikan atau pembelajaran, sehingga dapat diusahakan langkah-langkah perbaikan untuk menentukan mutu pendidikan di sekolah.

Terkait dengan fungsi evaluasi memang cukup luas, bergantung dari sudut mana kita melihatnya. Bila kita lihat secara menyeluruh, fungsi evaluasi adalah sebagai berikut: ${ }^{12}$

1. Secara psikologis, peserta didik selalu butuh untuk mengetahui

\footnotetext{
9 Arifin, Zainal. 2010. Evaluasi Pembelajaran.

Remaja Rosdakarya: Bandung. hal: 14.

10 Tylor, R. W. Basic Principles of Curriculum and Instruction (Chicago: Chicago University Press, 1967), h.13

11 Mukhtar. 2003. Desain Pembelajaran Pendidikan Agama Islam. Misaka Galiza: Jakarta. hal: 153

12 Ibid, h. 16-17
}

sejauh mana kegiatan yang telah dilakukan sesuai dengan tujuan yang hendak dicapai.

2. Secara sosiologis, evaluasi berfungsi untuk mengetahui apakah peserta didik sudah cukup mampu untuk terjun ke masyarakat.

3. Secara didaktis-metodis, evaluasi berfungsi untuk membantu guru dalam menempatkan peserta didik pada kelompok tertentu sesuai dengan kemampuan dan kecakapannya masing-masing serta membantu guru dalam usaha memperbaiki proses pembelajarannya.

4. Evaluasi berfungsi untuk mengetahui kedudukan peserta didik dalam kelompok, apakah dia termasuk anak yang pandai, sedang atau kurang pandai.

5. Evaluasi berfungsi untuk mengetahui taraf kesiapan peserta didik dalam menempuh program pendidikannya.

6. Evaluasi berfungsi untuk membantu guru dalam memberikan bimbingan dan seleksi, baik dalam rangka menentukan jenis pendidikan, jurusan maupun kenaikan kelas.

7. Secara administratif, evaluasi berfungsi untuk memberikan laporan tentang kemajuan peserta didik kepada orang tua, pejabat pemerintah yang berwenang, kepala sekolah, guru-guru dan peserta didik itu sendiri.

Secara umum, ada empat fungsi evaluasi dalam pendidikan Islam yaitu:

1. Dari segi pendidikan, evaluasi berfungsi untuk membantu seorang pendidik mengetahui sejauh mana hasil yang dicapai dalam pelaksanaan tugasnya.

2. Dari segi peserta didik, evaluasi membantu peserta didik untuk dapat mengubah atau mengubah tingkah lakunya secara sadar kearah yang lebih baik. 
3. Dari segi ahli pemikir pendidikan islam, evaluasi berfungsi untuk membantu para pemikir pendidikan islam mengetahui kelemahan teoriteori pendidikan islam dan membantu mereka dalam merumuskan kembali teori-teori pendidikan islam yang relevan dengan arus dinamika zaman yang senantiasa berubah.

4. Dari segi politik pengambil kebijakan pendidikan islam (pemerintahan) evaluasi berfungsi untuk membantu mereka dalam membenahi sistem pengawasan dan mempertimbangankan kebijakan yang akan diterapkan dalam sistem pendidikan islam.

\section{Manfaat Evaluasi}

1. Manfaat bagi siswa

a. Siswa dapat mengetahui hasil evaluasi memuaskan atau tidak memuaskan.

b. Siswa dapat mengetahui sejauh mana telah berhasil mengikuti pelajaran yang diberikan oleh guru.

2. Manfaat bagi guru.

a. Guru akan mengetahui siswasiswa mana yang sudah menguasai bahan pelajarannya.

b. Guru akan mengetahui apakah materi yang diajarkan sudah tepat bagi siswa.

c. Guru akan mengetahui apakah metode yang diberikan sudah tepat atau belum.

3. Manfaat Bagi sekolah

a. Dengan evaluasi dapat diketahui kondisi belajar yang dilangsungkan di sekolah.

b. Informasi guru tentang tepat tidaknya kurikulum sekolah, sebagai bahan pertimbangan bagi perencanaan sekolah untuk masa-masa yang akan datang.

c. Informasi hasil penilaian yang diperoleh dari tahun ke tahun dapat digunakan sebagai pedoman bagi sekolah, yang dilakukan oleh sekolah sudah memenuhi standart atau belum. Pemenuhan standart akan terlihat dari bagusnya angkaangka yang diperoleh.

\section{Prinsip Evaluasi Pendidikan}

Ada satu prinsip umum dan penting dalam kegiatan evaluasi, yaitu adanya triangulasi atau hubungan erat tiga komponen, yaitu:

1. Tujuan pembelajaran

2. Kegiatan pembelajaran atau KBM, dan

3. Evaluasi

Triangulasi tersebut dapat digambarkan dalam bagan sebagai berikut: ${ }^{13}$

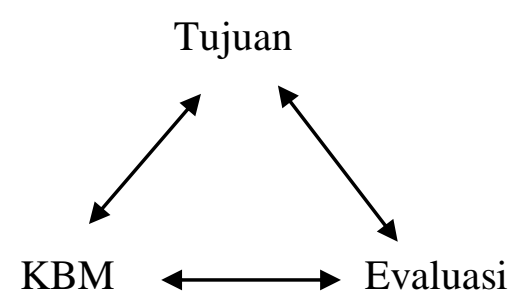

Keterangan:

a. Hubungan antara Tujuan dengan KBM

Kegiatan belajar mengajar yang dirancang dalam bentuk rencana mengajar disusun oleh guru dengan mengacu pada tujuan yang hendak dicapai. Dengan demikian, anak panah yang menunjukan hubungan antara keduanya mengarah pada tujuan dengan makna bahwa KBM mengacu pada tujuan, tetapi juga mengarah dari tujuan ke KBM, menunjukkan langkah dari tujuan dilanjutkan pemikirannya ke KBM.

b. Hubungan antara Tujuan dengan

Evaluasi

Evaluasi adalah kegiatan pengumpulan data untuk mengukur sejauh mana tujuan sudah tercapai.

13 Arikunto, Suharsimi. 2012. Dasar-dasar Evaluasi Pendidikan (Jakarta: Bumi Aksara) cet. ke 10, hal: 38 
Dengan demikian maka anak panah berasal dari evaluasi menuju ke tujuan. Di lain sisi, jika dilihat dari langkah, dalam menyusun alat evaluasi ia mengacu pada tujuan yang sudah dirumuskan.

c. Hubungan antara KBM dengan

Evaluasi

KBM dirancang dan disusun dengan mengacu pada tujuan yang telah dirumuskan. Kemudian alat evaluasi juga disusun dengan mengacu pada tujuan. Selain mengacu pada tujuan, evaluasi juga harus mengacu atau disesuaikan dengan KBM yang dilaksanakan. Dimisalkan, jika kegiatan belajar mengajar dilakukan oleh guru dengan menitik beratkan pada keterampilan, evaluasinya juga harus mengukur tingkat keterampilan siswa, bukannya aspek pengetahuan.

\section{Evaluasi Dilaksanakan Secara Objektif}

Objektif dalam arti bahwa evaluasi tersebut dilaksanakan dengan sebaik-baiknya, berdasarkan fakta dan data yang ada tanpa dipengaruhi oleh unsur-unsur subjektivitas dan evaluator (penilai). Objektivitas dalam evaluasi antara lain ditujukkan dalam sikap-sikap evaluator sebagai berikut:

a. Sikap ash-shidqoh, yakni berlaku benar dan jujur dalam mengadakan evaluasi, sikap ini diperintahkan oleh allah sebagai mana firmanNya:

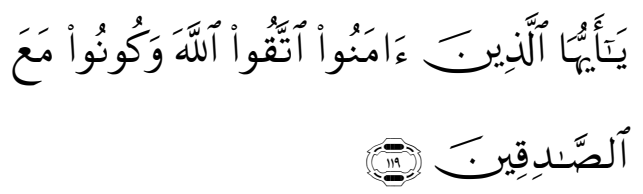

"Hai orang-orang yang beriman bertakwalah kepada Allah, dan hendaklah kamu bersama orangorang yang benar" (Qs. At-taubah (9): 119) b. Sikap amanah, yakni suatu sikap pribadi yang setia, tulus hati dan jujur dalam menjalankan sesutu yang diamanahkan (dipercayakan) kepadanya. Sikap ini diperintahkan oleh allah berdasarkan firman-Nya:

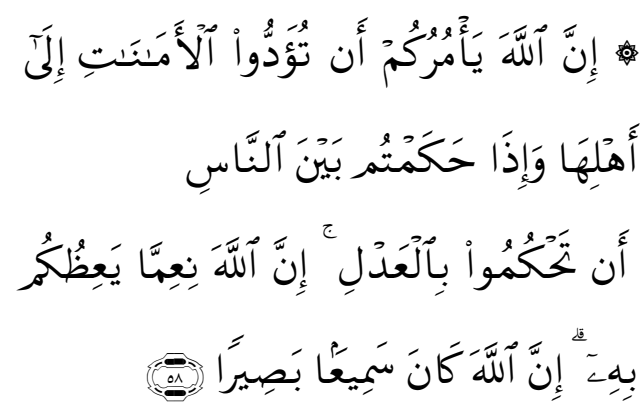

"Sesungguhnya Allah menyuruh kamu menyampaikan amanat kepada yang berhak menerimanya, dan (menyuruh kamu) apabila menetapkan hukum di antara manusia supaya kamu menetapkan dengan adil. Sesungguhnya Allah memberi pengajaran yang sebaikbaiknya kepadamu. Sesungguhnya Allah adalah Maha mendengar lagi Maha melihat". (Qs. Annisa(4):58).

\section{Jenis-jenis Evaluasi Pendidikan}

Berbicara mengenai jenis-jenis evaluasi pendidikan, hal ini dapat diklasifikasikan dalam tiga segi, sebagai berikut:

1. Klasifikasi dilihat dari fungsinya.

a. Evaluasi formatif yaitu evaluasi yang menetapkan tingkat penguasaan peserta didik dan menentukan bagian-bagian tugas yang belum dikuasai dengan tepat.

b. Evaluasi sumatif, yaitu penilaian secara umum tentang keseluruhan hasil dari proses belajar mengajar yang dilakukan pada setiap akhir periode belajar mengajar secara terpadu.

c. Evaluasi diagnostik ialah penilaian yang dipusatkan pada proses belajar mengajar dengan 
melokalisasikan suatu titik keberangkatan yang cocok.

d. Evaluasi penempatan (placement evaluation) yang menitik beratkan pada penilaian berbagai permasalahan yang berkaitan dengan:

1) Ilmu pengetahuan dan keterampilan peserta didik yang di perlukan untuk awal proses belajar mengajar.

2) Pengetahuan peserta didik tentang tujuan pengajaran yang telah di tetapkan sekolah.

3) Minat dan perhatian, kebiasaan bekerja, corak kepribadian yang menonjol yang mengandung konotasi kepada suatu metode tertentu.

2. Klasifikasi evaluasi dilihat dari caranya.

a. Evaluasi kuantitatif, dinyatakan dengan angka dapat dilakukan untuk menilai aspek-aspek tingkah laku peserta didik dalam bidang kognitif.

b. Evaluasi kualitatif, dinyatakan dengan ungkapan dan dilakukan untuk menilai aspek-aspek afektif.

Kedua cara evaluasi tersebut membutuhkan tehnik pelaksanaan, yaitu tehnik tes dan non-tes.

3. Klasifikasi dilihat dari tehniknya.

a. Tehnik tes; dibedakan menurut materi yang akan dinilai, bentuk, dan cara membuatnya.

b. Tehnik non-tes; dapat dilaksanakan melalui pengamatan, wawancara, angket, hasil karya/laporan dan skala sikap.

\section{Sasaran Evaluasi}

Merupakan tindakan yang harus ditempuh oleh pendidik dalam mengadakan evaluasi. Menurut Tabrani Rusyan dalam Abuddin Nata
(1997:143), yang menjadi sasaran pokok evaluasi tersebut, yaitu:

1. Segi tingkah laku yaitu segi-segi yang menyangkut sikap, minat, perhatian, keterampilan peserta didik sebagai akibat dari proses belajar mengajar.

2. Segi pendidikan yaitu penguasaan materi pelajaran yang diberikan oleh pendidik dalam proses belajar mengajar.

3. Segi-segi yang menyangkut proses belajar mengajar, yaitu bahwa proses belajar mengajar perlu diberi penilaian secara objektif dari pendidik.

\section{Syarat-syarat Evaluasi Pendidikan Islam}

Syarat-syarat yang dapat di penuhi dalam proses evaluasi pendidikan islam yaitu:
1. Validity.
2. Reliable.
3. Efisiensi.

\section{Evaluasi dalam Pendidikan Islam}

Evaluasi ini mencakup evaluasi hasil belajar dan evaluasi pembelajaran, maka seorang pendidik harus dapat membedakan mana yang kegiatan evaluasi hasil belajar dan mana yang kegiatan evaluasi pembelajaran. Evaluasi hasil belajar menekankan pada pencapaian informasi tentang seberapakah hasil belajar yang dicapai oleh siswa sesuai dengan tujuan yang telah ditetapkan, sedangkan evaluasi pembelajaran merupakan suatu proses yang sistematis untuk memperoleh informasi tentang keefektifan proses pembelajaran dalam membantu siswa mencapai tujuan yang telah ditetapkan secara optimal.

\section{KESIMPULAN}

Evaluasi merupakan salah satu komponen sistem pembelajaran pada 
khususnya, dan sistem pendidikan pada umumnya. Artinya, evaluasi merupakan suatu kegiatan yang tidak mungkin dielakkan dalam setiap proses pembelajaran. Dengan kata lain, kegiatan evaluasi, baik evaluasi hasil belajar maupun evaluasi pembelajaran, merupakan bagian integral yang tidak terpisahkan dari kegiatan pembelajaran atau pendidikan.

Pendidikan Islam merupakan pendidikan yang didasarkan pada nilai-nilai ajaran Islam sebagaimana tercantum dalam al-Qur'an dan al-Hadits serta dalam pemikiran para ulama dan dalam praktik sejarah umat Islam. Dalam prosesnya, pendidikan Islam menjadikan tujuan sebagai sasaran ideal yang hendak dicapai dalam program dan diproses dalam produk kependidikan Islam atau output kependidikan Islam dengan tolok ukur hasil pendidikan dapat diketahui dengan adanya evaluasi.

\section{DAFTAR PUSTAKA}

Abudin Nata. 2010. Ilmu Pendidikan Islam. Kencana Prenada Media Group: Jakarta.

Abudin Nata, 2008. Manajemen Pendidikan, Mengatasi Kelemahan
Pendidikan Islam di Indonesia. Prenada Media Group: Jakarta.

Abdul Mujib dan Jusuf Mudzakkir. 2008. Ilmu Pendidikan Islam.

Kencana Prenada Media Group: Jakarta.

Al-Rasyidin dkk. 2005. Filsafat Pendidikan Islam Pendekatan Historis, teoritis dan Praktis, Ciputat Press: Jakarta.

Arikunto, Suharsimi. 2012. Dasar-Dasar Evaluasi Pendidikan. Bumi Aksara: Jakarta.

Arifin, Zainal. 2010. Evaluasi Pembelajaran. Remaja Rosdakarya: Bandung.

M. Arifin. 2009. Ilmu Pendidikan Islam, Tinjauan Teoritis dan Praktis Berdasarkan Pendekatan Interdisipliner. Bumi Aksara: Jakarta.

Mukhtar. 2003. Desain Pembelajaran Pendidikan Agama Islam. Misaka Galiza: Jakarta.

Ramayulis. 2008. Ilmu Pendidikan Islam. Kalam Mulia: Jakarta.

Tylor, R. W. 1967. Basic Principles of Curriculum and Instruction. Chicago University Press: Chicago. 